\title{
(1) Experimental and Mesoscopic Lattice Numerical Investigation of Increase of Chloride Diffusivity Coefficient during Uniaxial Loading Model
}

\author{
Bui TRUONG SON ${ }^{1, *}$, Pham DUC THO ${ }^{1)}$, Tran THE TRUYEN ${ }^{2)}$, \\ Nguyen THI NU'), Vu MINH NGOC ${ }^{3,4)}$
}

\footnotetext{
1) University of Mining and Geology, Hanoi, Vietnam; email: buitruongson@humg.edu.vn; phamductho@humg.edu.vn; nguyenthinu@humg.edu.vn

2) University of Transport and Communications, Hanoi, Vietnam; email: tranthetruyen@utc.edu.vn

3) Institute for Computational Science, Ton Duc Thang University, Ho Chi Minh City, Vietnam; email: vuminhngoc@tdtu.edu.vn

4) Faculty of Civil Engineering, Ton Duc Thang University, Ho Chi Minh City, Vietnam; email: vuminhngoc@tdtu.edu.vn
}

http://doi.org/10.29227/IM-2020-02-05

Submission date: 06-03-2020 | Review date: 22-09-2020

\section{Abstract}

This paper presents experimental and simulation results of the change in the chloride diffusion coefficient of concrete C40 ( $f^{\prime} c=40$ $\mathrm{MPa}$ ) during axial loading. Test Method for Electrical Indication was used to measure the chloride diffusivity of the concrete sample during the axial loading. A mesoscopic lattice model is proposed to describe the variation of chloride diffusion coefficient versus damage variable. In such a model, the domain of material is discretized randomly by using Voronoi tessellation for the transport element and Delaunay triangulation for a mechanical element. At the mesoscale, the concrete is constituted by three phases: aggregate, cement paste and ITZ, in which aggregate is assumed to be elastic while cement matrix and ITZ are represented by a damage model with softening. The experimental and numerical results show that in the first stage, without crack $(s<40 \%$ smax), the chloride diffusion coefficient remains almost constant, however in the crack initiation and propagation stage ( $s=60-80 \%$ smax) chloride diffusion coefficient increases significantly. An empirical power model is also proposed to describe the increase of the chloride diffusion coefficient versus stress level and damage variable.

Keywords: lattice model, durability of concrete, coastal regions, chloride diffusion

\section{Introduction}

The service life of a concrete structure is the period from the construction stage to structural damage exceeding safety requirements. In coastal condition, many deteriorating attacks lead to the steel corrosion in reinforced concrete, in which chloride ingress into a structure is the cause of the corrosion (Tuutti et al. 1982). This reduces the service life of the reinforced concrete structure in the coastal region.

The chloride diffusivity of concrete depends on two main factors: interconnected porosity of cement paste and micro-cracks. The second one is controlled by the stress level and path, while the first one is essentially influenced by the ratio water/cement, the compaction and the hydration degrees. In the case of more cracks, an increase in the chloride diffusivity coefficient leads to the deterioration of reinforced concrete and a decrease in the durability and longevity of the structures. Therefore, the simultaneous consideration of the environmental impact and the load on the durability of reinforced concrete structures is necessary and is a new research trend in recent years (Wang et al., 2016; Nguyen et al. 2015; Yang et al. 2019). In particular, the effect of stress on permeability change is a key issue for determining the service life of the structures.

Many methods have been developed to determine the chloride diffusivity. Effect of damage on the chloride diffusivity coefficient and durability of reinforced concrete structures has widely studied (Garboczi et al. 1990; Picandet et al. 2001; Bhargava et al. 2008; Samaha and Hover, 1992; Saito and Ishi- mori, 1995; Wang et al., 2016). Many different experimental models were used for the investigation of the chloride diffusion coefficient (Yang et al., 2004; Yang et al. 2019; Banthia et al. 2005; Bhargava et al., 2008). However, the test results presented in the literature exhibit a significant variability. This is due to the fact that the chloride diffusion resistance of concrete has been determined by many methods with direct or indirect control loads and different sample sizes. The chloride migration test at three loading conditions (without loading, under loading and after unloading) is a common method to evaluate the chloride diffusion coefficient of concrete (Ahmad Shamsad et al., 2004 Wang et al., 2016, Teggur, et al., 2013). However, it is very different from the practical environment, in which the loading and chloride ion diffusion is coupling simultaneously, and it would mislead the designation of the concrete structure. Thus, it is necessary to study the effect of load on the chloride diffusivity coefficient. The experimental results also show that the chloride diffusivity coefficient slightly changed when the stress level exceeds $70 \%$ of the ultimate strength (Saito and Ishimori, 1995; Tran et al., 2017). Tung et al. (2017) studied the change of chloride diffusivity coefficient of concrete during uniaxial loading and showed that the chloride diffusivity coefficient increased rapidly during compressive stress ratio $\sigma / \sigma \max =0.6-0.8$. Nguyen and Tran (2015) measured the chloride diffusivity coefficient of samples under different load levels ( $\sigma / \sigma \max )$ and indicated that the compressive stress affects the water permeability and chloride diffusivity of concrete significantly. 

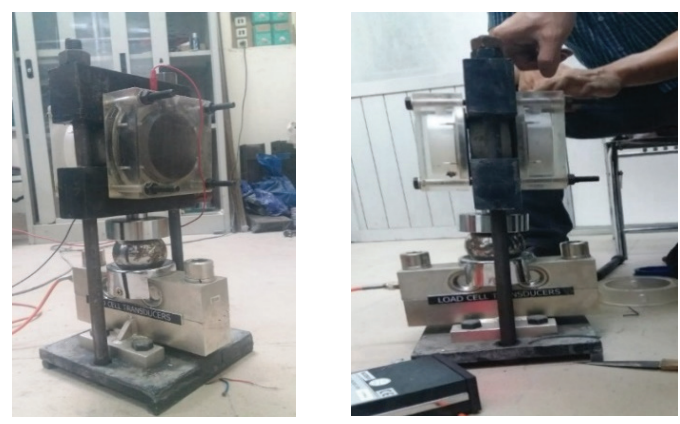

Fig. 1. Experimental set up for chloride migration test under compressive stress

Rys. 1. Układ doświadczalny do badania migracji chlorków pod wpływem naprężenia ściskającego

Tab. 1. Concrete $\mathrm{C} 40$ mixture design

Tab. 1. Projekt mieszanki betonowej C40

\begin{tabular}{|c|c|c|c|c|c|}
\hline Type of concrete & Cement $(\mathrm{kg})$ & Fine aggregates $(\mathrm{kg})$ & Coarse aggregates $(\mathrm{kg})$ & $\begin{array}{c}\text { Water } \\
(\mathrm{kg})\end{array}$ & Ratio of w/c \\
\hline $\mathrm{C} 40$ & 472 & 626 & 1197 & 170 & 0.36 \\
\hline
\end{tabular}

The dependency of chloride diffusion on the compressive stress and/or damage variable has been considered by both experimental and numerical approaches (Bhargava and Banthia, 2008, Garboczi, 1990, Djerbi et al., 2008; Grassl, 2009; $\mathrm{Vu}$ et al. 2012, 2015, 2018). The drawback of the previous models is a macroscopic model. The compressive stress-induced micro-cracks, which controlled the change of chloride diffusivity, has not fully described yet. Indeed, concrete is considered as a homogeneous material in the previous investigation. Those approaches do not allow taking into account the local damage due to the incompatible deformation between the cement paste and aggregates. Crack occurring in the homogeneous model is often perpendicular to the rusted steel, whereas cracks exist in the form of zigzag in reality due to the presence of aggregates. Therefore, this paper aims to propose a mesoscopic lattice model to describe the damage induced change in chloride diffusivity of concrete material. Test measurement was also carried out to validate the current model At the mesoscale, concrete includes three phases: aggregate, cement paste and interfacial transition zone (ITZ), in which ITZ is the interface between aggregate and surrounding matrix. ITZ presents as a weakness zone for both mechanical and transport aspects. Aggregates are assumed to be elastic, whilst cement matrix and ITZ are modelled by an elastic-damage with softening model. The chloride diffusion is described by Fick law. The dependency of the chloride diffusivity on the damage variable is taken into account from the empirical relation proposed by Picandet (2001). Comparison between the proposed model and experimental result was made to show the predictive ability of the proposed lattice model.

\section{Materials and methods \\ The experiment method}

The rapid chloride penetrability test in accordance with ASTM C1202 and AASHTO T277-86 was used in this study to assess the chloride diffusivity of the considered concrete. The mixture proportion of concrete C40 is shown in Tab 1. The aggregate was designed according to ASTM C33, in which the fine aggregates were natural river sand and the coarse aggregates were crushed gravel with the maximum size of 15 $\mathrm{mm}$. Cement was made with respect to ASTM C150. Con- crete samples were prepared in two different groups. Group A includes cylindrical concrete samples with $300 \mathrm{~mm}$ in height and $150 \mathrm{~mm}$ in diameter. Group B are cylindrical concrete samples with a height of $200 \mathrm{~mm}$ and a diameter of $100 \mathrm{~mm}$. After curing for 28 days, Group A was tested to determine the compressive strength of concrete ( $\sigma$ max), Group B was used for chloride ion permeability test, which was cut into two samples (the cylinder of $50 \mathrm{~mm}$ in height and $100 \mathrm{~mm}$ in diameter) and coated with epoxy glue on the surrounding surface to ensure only allow diffusion of chloride ions to intrude one way. The samples were cleaned surface before installing into the equipment.

The chloride ion permeability tests were performed at different stress levels of $0 \% \sigma \max , 40 \%$ omax; $60 \%$ omax; $80 \%$ omax. During chloride ion permeability tests, each stress level was kept constant, the sample was exposed with chloride solution and connected to a computer system to automatically determine the total amount of electricity transferred through the sample (Fig 1). The chloride diffusion coefficient through concrete was determined by the value of total electric quantity transmitted through the test sample (Ahmad, 2004). Based on the record of electric current, the chloride diffusion coefficient was calculated (Ahmad, 2004).

\section{Numerical modelling}

Lattice discretization

The lattice discretization is performed by the generation of a dual system of Delaunay triangulation and Voronoi diagram (Voronoi, 1908). Conduit elements are placed along the edges of the Voronoi diagram. Whereas, the mechanical elements are considered as beam form elements (transmission of normal force, shear force, and bending moment) which placed on the sides of Delaunay triangulation (Fig 2a). This dual system is built by a random generation of nodes. The density of nodes is higher in the regions close to corners and boundary of domain than the rest of the domain to assure a good transmission of prescribed boundary condition. Moreover, in order to ensure a good Voronoi structure, the distance between the points on the boundary is smaller than that of the points inside. Each point distributed in the study domain will be tested to satisfy the distance from that point 

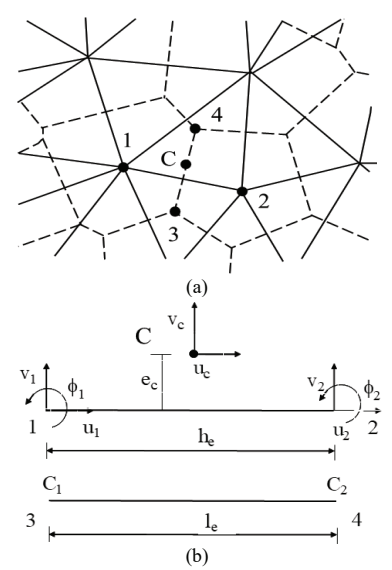

Fig. 2. a) Delaunay triangulation and Voronoi diagram; b) Mechanical elements Rys. 2. a) Triangulacja Delaunaya i diagram Woronoja; b) Elementy mechaniczne
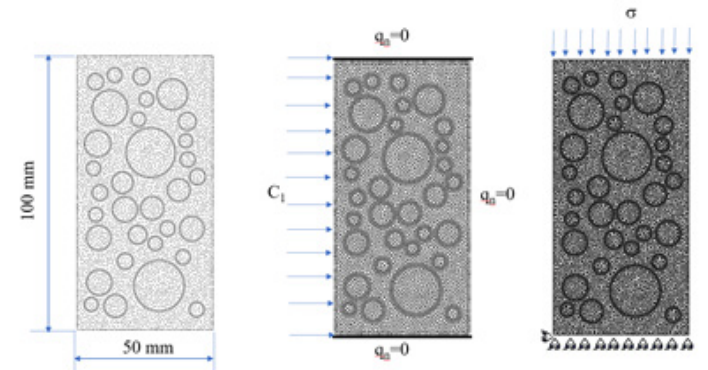

Fig. 3. 2D geometric model for the problem of chloride diffusion under compressive loading R ys. 3. Model 2D dla problemu dyfuzji chlorków pod obciążeniem ściskającym

to surrounding points is greater than the minimum distance (dmin). A detail of the dual system building can be found in (Grassl, 2009; Grassl, 2011; Voronoi, 1908 ).

\section{Mechanical lattice model}

Mechanical elements are located on the edges of Delaunay triangles. Each node has three degrees of freedom, including two translations $(\mathrm{u}, \mathrm{v})$, and one rotation $(\phi)$. These translations and rotation at two nodes of a mechanical element allow determining the mechanical variable at the midpoint $\mathrm{C}$ where the hydro-mechanical coupling takes place (Fig 2b).

At the midpoint $\mathrm{C}$ of the cross-section, discontinuous displacement is determined as follows:

$$
\begin{gathered}
u_{c}=B u_{e} \\
u_{e}=\left\{u_{1}, v_{1}, \varphi_{1}, u_{2}, v_{2}, \varphi_{2}\right\}^{T} \\
u_{c}=\left\{u_{c}, v_{c}\right\}^{T} \\
B=\left[\begin{array}{cccccc}
-1 & 0 & e_{c} & 1 & 0 & -e_{c} \\
0 & -1 & -h_{e} / 2 & 0 & 1 & -h_{e} / 2
\end{array}\right]
\end{gathered}
$$

$h_{e}$ is the length of the mechanical element; $e_{c}$ is the eccentricity of point $\mathrm{C}$ to the axis of the mechanical element.

The displacement $u_{c}$ is replaced by strain $\varepsilon=u_{c} / h_{e}=\left(\varepsilon_{n}, \varepsilon_{s}\right)$; $\varepsilon_{\mathrm{n}}, \varepsilon_{\mathrm{s}}$, are normal and shear strain.

The stiffness of a lattice element is determined as follows:

$$
K=\frac{A}{h_{e}} B^{T} D_{e} B
$$

In the case of the isotropic damage model, the relationship between strain and stress was determined by Grassl (2009, 2011, 2015); Pham et al., (2019); Pham et al., (2020); Nguyen et al., (2019). The development of damage is controlled by the stress-crack opening relation, and the mechanical behaviour is independent on the length of the lattice element. The relationship between stress and strain is expressed as follows:

$$
\sigma=(1-\omega) D_{e} \varepsilon=(1-\omega) \bar{\sigma}
$$

where $\sigma$ is damage coefficient, $\sigma=\left(\sigma_{n}, \sigma_{\mathrm{s}}\right)^{\mathrm{T}}$ and the stiffness matrix $\mathrm{D}_{\mathrm{e}}$ is determined as follows:

$$
D_{e}=\left[\begin{array}{cc}
E & 0 \\
0 & \gamma E
\end{array}\right]
$$

where $\mathrm{E}$ and $\gamma$ are the parameters of the model. In the case of plane stress and uniform lattice mesh, Poisson's coefficient $(v)$ is denoted as follows:

$$
v=\frac{1-\gamma}{3+\gamma}
$$

The damage coefficient $\omega$ is a function of a history index variable $\kappa$, is determined by a loading function:

$$
f(\varepsilon, \kappa)=\varepsilon_{\text {eq }}(\varepsilon)-\kappa
$$

Equivalent strain $\varepsilon_{\mathrm{eq}}$ is determined:

$$
\varepsilon_{e q}\left(\varepsilon_{s}, \varepsilon_{n}\right)=\frac{1}{2} \varepsilon_{0}(1-c)+\sqrt{\left(\frac{1}{2} \varepsilon_{0}(c-1)+\varepsilon_{n}\right)^{2}+\frac{c \lambda^{2} \varepsilon_{s}^{2}}{q^{2}}}
$$

where $\mathrm{D}_{\mathrm{e}}$ is the stiffness matrix. 
Tab. 2. Mechanical and hydraulic model parameters

Tab. 2. Parametry modelu mechanicznego i hydraulicznego

\begin{tabular}{|l|c|c|c|c|c|c|c|}
\hline & $\begin{array}{c}E \\
(\mathrm{GPa})\end{array}$ & $\begin{array}{c}\gamma \\
(-)\end{array}$ & $\begin{array}{c}f_{\mathrm{t}} \\
(\mathrm{MPa})\end{array}$ & $f_{\mathrm{s}}(\mathrm{MPa})$ & $f_{\mathrm{c}}(\mathrm{MPa})$ & $\begin{array}{c}G_{\mathrm{fc}} \\
\left(\mathrm{J} / \mathrm{m}^{2}\right)\end{array}$ & $\begin{array}{c}D_{c} \\
\left(\mathrm{~m}^{2} / \mathrm{s}\right)\end{array}$ \\
\hline Coarse aggregate & 70 & 0.08 & - & - & - & - & - \\
\hline Cement mortar & 29.5 & 0.33 & 3.8 & 7.6 & 76 & $8 \times 10^{5}$ & $6.2 \times 10^{-12}$ \\
\hline$I T Z$ & 41.5 & 0.20 & 3 & 6 & 60 & $1.5 \times 10^{5}$ & $6.2 \times 10^{-12}$ \\
\hline
\end{tabular}
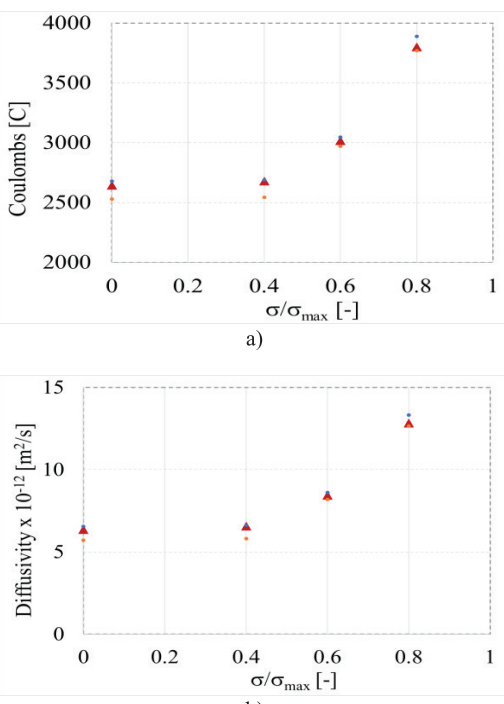

b)

Fig. 4. a) Electric energy through concrete, b) Chloride diffusion coefficient Rys. 4. a) Energia elektryczna przez beton, b) Współczynnik dyfuzji chlorków

where $\varepsilon_{0}, c, q, \lambda$ are the parameters of the lattice model. These parameters directly depend on the compressive strength and the stiffness of lattice elements. According to (Grassl 2009; Pham et al., 2019), the equivalent strain only depends on two strains of $\varepsilon_{\mathrm{n}}, \varepsilon_{\mathrm{s}}$.

The softening curve of the stress-strain response is controlled by the fracture energy $\mathrm{G}_{\mathrm{fc}}$ (for the case of pure compression or $\mathrm{G}_{\mathrm{ft}}$ (for the case of pure tension):

$$
\sigma_{n}=f_{i} e^{\left(-\frac{e}{\omega_{i}}\right)}
$$

with $\mathrm{i}=\mathrm{c}\left(\right.$ compression) or $\mathrm{t}($ tension $) ; \omega \mathrm{i}=\mathrm{G}_{\mathrm{fi}} / \mathrm{f}_{\mathrm{i}} ; \mathrm{e}=\|\mathrm{e}\|$ is the equivalent crack opening parameter.

$\mathrm{e}=\mathrm{h}_{\mathrm{e}}^{-} \omega \varepsilon$

In case of pure compression:

$\mathrm{f}_{\mathrm{t}}=\mathrm{E} \varepsilon_{0}$

In case of pure tension:

$\mathrm{f}_{\mathrm{c}}=\mathrm{cf}_{\mathrm{t}}$

The damage coefficient is defined by solving the equation:

$(1-\omega) \kappa=c \varepsilon_{0} \exp \left(-\frac{h_{e} d \kappa}{G_{f i} / f_{i}}\right)(i=c, t)$

\section{Chloride diffusion lattice model}

Chloride ingress also takes places in the transport elements, i.e. edges of the Voronoi polygons. The chloride diffu- sion model in concrete was based on Fick's second equation. The equation describing chloride diffusion in a one-dimensional case, for each element, is determined as follows:

$$
D_{e} C+C_{e} \frac{\partial C}{\partial t}=f
$$

where $\mathrm{D}_{\mathrm{e}}$ is diffusion matrix of the element, $\mathrm{C}_{\mathrm{e}}$ is a capacity matrix of the element, $t$ is time, $\mathrm{f}$ is an external source

$$
D_{e}=\frac{h_{e}}{l_{e}} D_{t}\left(\begin{array}{cc}
1 & -1 \\
-1 & 1
\end{array}\right) \quad ; \quad C_{e}=\frac{h_{e} l_{e}}{12}\left(\begin{array}{ll}
2 & 1 \\
1 & 2
\end{array}\right)
$$

where $h_{e}$ is the length of the mechanical element, $l_{e}$ is the length of tubular elements, $D_{t}$ is the diffusion coefficient of elements.

The increase in the diffusion coefficient is caused by damage calculated as follows (Picandet, 2001):

$$
D_{t}=D_{\text {und }}\left(1+\exp \left[(\alpha \omega)^{\beta}\right]\right)
$$

where $\mathrm{D}_{\text {und }}$ is the diffusion coefficient of original materials of concrete without deterioration, $\alpha, \beta$ are the parameters of the model, for the case of concrete, $\alpha=11.3, \beta=1.64$.

Predicting of the increase in the chloride diffusion coefficient of concrete under loading

Concrete sample is model at a mesoscale with three different phases: elastic aggregate and mortar, ITZ represented by an elastic-damage model. Aggregate is much solid than ITZ and cement paste. Under a sufficient compressive stress level, the concrete can be damaged, which initiates and developpes firstly in the ITZ zone and then in the cement ma- 

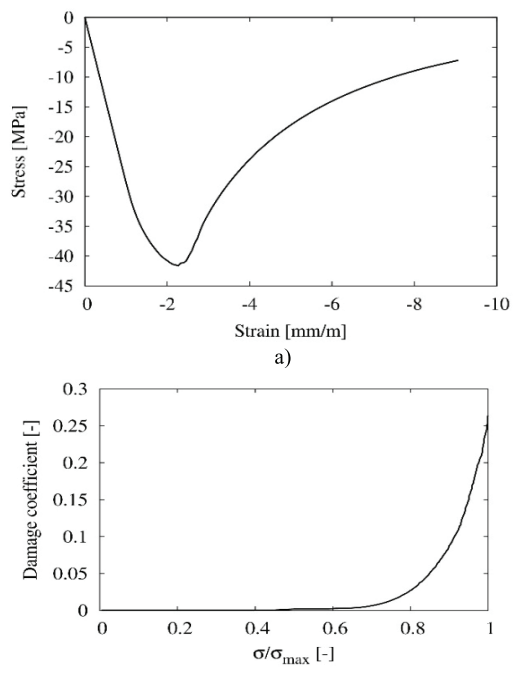

Fig. 5. a) Stress-strain; b) Damage coefficient - stress level

Ryc.5. a) stres-odkształcenie; b) Współczynnik uszkodzenia - poziom naprężenia

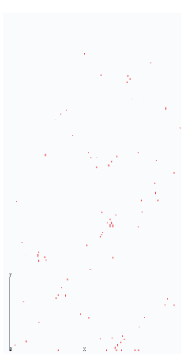

a)

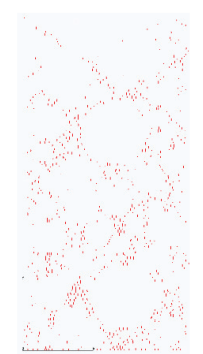

b)

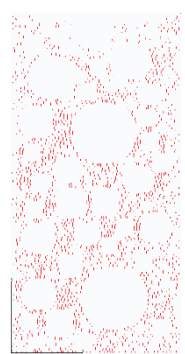

c)

Fig. 6. a) Micro-cracks at stress level $\sigma=40 \% \sigma \mathrm{max}$; b) micro-cracks at stress level $\sigma=60 \% \sigma \mathrm{max}$; ) micro-cracks at stress level $\sigma=80 \% \sigma \mathrm{max}$ Rys. 6. a) Mikropęknięcia na poziomie naprężenia $\sigma=40 \%$ omax; b) mikropęknięcia na poziomie naprężenia $\sigma=60 \%$ omax; c) mikropęknięcia na poziomie naprężenia $=80 \%$ omax

trix. When the uniaxial compressive stress varies from 0 to $100 \% \sigma \max$, the concrete sample passes two stages: elastic behaviour $(\sigma / \sigma \max \leq 0.5)$ and plastic hardening (pre-peak) $(0.5$ $<\sigma / \sigma \max <1.0)$.

\section{Geometric dimensions and initial conditions}

In the $2 \mathrm{D}$ geometric model, the concrete sample has dimensions of $100 \times 50 \mathrm{~mm}^{2}$. The aggregates are assumed to be circular with the diameter varies from 5 to $15 \mathrm{~mm}$, and randomly distributed in the model. Then the study domain is discrete into the Voronoi polygon and Delaunay triangulation. The edges of the Voronoi polygon are considered as pipes that allow the transport of chloride ions from the external environment into the concrete while the edges of Delaunay triangles are considered as beam mechanical elements. By assuming the initial condition, the chloride ions concentration is zero (Fig 3).

\section{Boundary conditions}

- For the chloride diffusion problems: The concentration of chloride ion $\mathrm{C}_{1}$ is prescribed on the left surface of concrete sample and is constant, and the flow of chloride ion on the remaining surfaces is zero (Fig 3).

- For mechanical problems: $\mathrm{D}_{\mathrm{y}}=0$ is prescribed on the bottom surface and $\mathrm{D}_{\mathrm{x}}=0$ at the bottom corner on the left (Fig 3).
As a reminder, aggregate is assumed to be elastic and thus characterized by two parameters E and $\gamma$ relating to Young's modulus and Poisson ratio. Whereas, cement and ITZ are represented by a damage-elasticity model that the stress-strain relation is fully described by seven parameters: Young's modulus; Poisson ratio; tensile strength $\left(\mathrm{f}_{\mathrm{t}}\right)$; compressive strength $\left(f_{c}\right)$; shear strength $\left(f_{s}\right)$; pure compression fracture energy Gfc. Mechanical parameters of concrete components first are estimated from the measured homogenized properties of concretes, measured properties of cement and then verified and adjusted against the experimental results obtained in this study. Tab 2 summaries all mechanical model parameters.

\section{Results and discussion \\ The experiment method}

The results show that the chloride diffusion coefficient does not change up to the stress level of $40 \%$ ultimate strength (Fig 4). Indeed, concrete is in the elastic response for $\sigma \leq 60 \%$ omax and thus there is no microcrack appearance. When stress level increases to $60 \%$ omax and $80 \%$ omax, the chloride diffusion coefficient of concrete increases by $36 \%$ and $108 \%$, respectively. This is due to the initiation and growth of microcracks within concrete sample under loading. Wang et al. (2016) studied the chloride migration coefficient of concrete under loading conditions and indicated that chloride migration coefficient changed little when the stress level was 


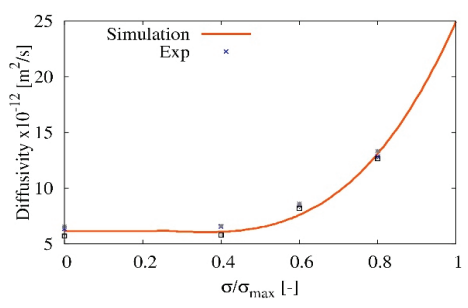

a)

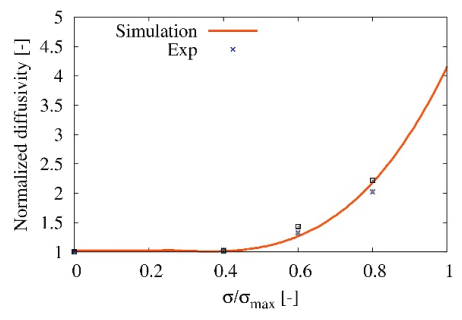

b)

Fig. 7. a) Chloride diffusion coefficient vs. stress level; b) Normalized chloride diffusion coefficient

Rys. 7. a) Współczynnik dyfuzji chlorków a poziom naprężenia; b) Znormalizowany współczynnik dyfuzji chlorków
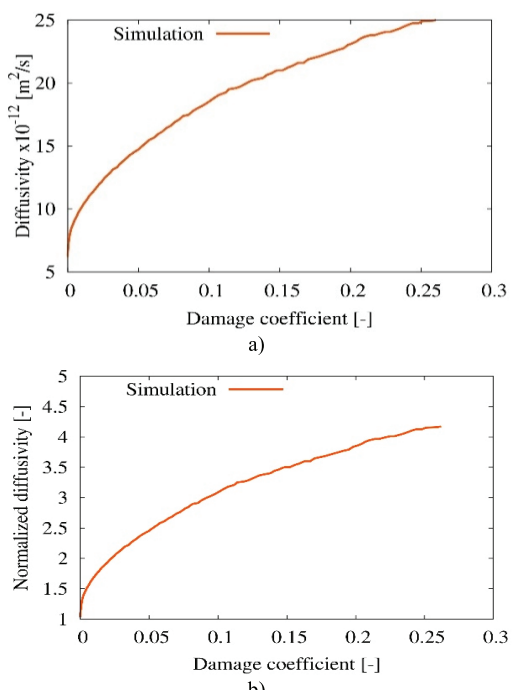

b)

Fig. 8. a) The relationship between the damage coefficient and the chloride diffusion coefficient; b) Normalized chloride diffusion coefficient Rys. 8. a) Zależność między współczynnikiem uszkodzenia a współczynnikiem dyfuzji chlorków; b) Znormalizowany współczynnik dyfuzji chlorków

below 50\% omax and chloride migration coefficient under loading of over $50 \%$ omax was $2-4$ times higher than that under without loading ( 2 times at $60 \%$ omax and four times at $100 \%$ omax).

\section{The lattice method}

The relationship between stress-strain of concrete under loading from the initial state to the failure state is provided in Fig $5 \mathrm{a}$. It can be seen that there are three stages of the stressstrain relationship. In the first stage, the stress-strain relationship is a liner which is associated with the elastic behaviour of concrete. In the second stage, when the stress exceeds the elastic limit, the stress-strain relationship is nonlinear, where the micro-cracks occur and develop but not yet coalesced in concrete. Finally, the third stage corresponds to the softening behaviour (post-peak) with $\varepsilon>2 \mathrm{~mm} / \mathrm{m}$. In this stage, the macro-cracks resulted from the coalescence of microcracks occur. It can be seen that at the stress level less than $40 \% \sigma \max$, concrete still behave in the elastic stage, and micro-cracks are rare, the damage coefficient is small and almost equals to zero. The damage coefficient increases rapidly at the stress level of $80 \%$ omax (Fig 5b). The micro-cracks at stress levels of $40 \% \sigma \max , 60 \% \sigma \max$ và $80 \% \sigma \max$ are presented in Fig 6.

Fig 7 presents both experimental and simulated results of the chloride diffusivity versus stress. It can be seen that when the stress is less than $40 \%$ max corresponding to the elastic stage, the chloride diffusion coefficient is constant. Then, the chloride diffusion coefficient increases as a function of uniaxial stress due to the initiation and growth of microcracks. The increase rate also increases versus $\sigma / \sigma \max$. At the compressive stress, i.e. $100 \% \sigma \max$, the chloride diffusion coefficient $\mathrm{D}=$ $25 \times 10-12\left(\mathrm{~m}^{2} / \mathrm{s}\right)$ and is about 4.2 time of the initial value.

Fig 8 shows the evolution of chloride diffusivity as a function of the damage variable of a concrete sample. The damage variable of the whole specimen is defined as the ratio between the unloading modulus and the initial modulus of the stress-strain curve.

In general, the simulation results are quite similar to the experiments, which shows the capacity of the proposed lat- 
tice model for the prediction of chloride diffusion coefficient change under different stress levels.

\section{Conclusions}

From the experimental and simulation results, some conclusions can be drawn:

- The chloride coefficient is almost constant when the stress is lower than $40 \%$ of the ultimate compressive strength of concrete (i.e. elastic stage);

- A good agreement between the proposed lattice model and test results is observed, which shows the predictive capacity of the proposed model;

- An increase in chloride diffusivity versus the uniaxial stress is observed. This increase is more pronounced when the stress is higher. Experimental and numerical results show the chloride diffusion coefficient is about $1.4 ; 2.1$, and 4.2 times of the initial value when the stress reaches $60 \%, 80 \%$ and $100 \% \sigma \max$.

- The proposed numerical model allows yielding a relation between the chloride diffusion coefficient and the damage variable.

- The current lattice model can be applied to predict the service time of structures due to chloride-induced reinforcement corrosion.

\section{Acknowledgements:}

We would like to thank Hanoi University of Ming and Geology for the provision of laboratory facilities used in this work and the support of Project (B2020-MDA-12) of Ministry of Education and Training to complete this study.

\section{Literatura - References}

1. AASHTO T277-86. Rapid determination of the chloride permeability of concrete, Standard Specifications Part II, Tests. American Association of States Highway and Transportation Officials, Washington, D.C. 1990.

2. ASTM C1202, Standard Test Method for Electrical Indication of Concrete's Ability to Resist Chloride Ion Penetration, 2012.

3. Ahmad Shamsad, Walid Al-KuttiOmar S.Baghabra Al-AmoudiOmar S.Baghabra Al-AmoudiM. Maslehuddin M. Maslehuddin. Correlations between depth of water penetration, Chloride permeability and Coefficient of Chloride diffusion in plain, Silica fume and Fly ash cement concretes. Journal of Testing and evaluation, 2004.

4. Banthia. N, Birpava. A, Mindess. S (2005), "Permeability of concrete under stress", Cement and Concrete Research35, 1651-1655, 2005.

5. Bhargava, A. and Banthia, N. Permeability of concrete with fiber reinforcement and service life predictions. Materials and Structures, 41, p.363-372, 2008.

6. Djerbi, A., Bonnet, S., Khelidj, A. and Baroghel -Bouny, V. Influence of traversing crack on chloride diffusion into concrete. Cement and Concrete Research, 38, p. 877-883, 2008.

7. Garboczi, J. Permeability, diffusivity and microstructural parameters: a critical review. Cement and Concrete Research, Vol 20, No 4, 1990, p.590-601.

8. Grassl, P. A lattice approach to model flow in cracked concrete. Cement and Concrete Composites. Vol 331 2009, p. 454-460.

9. Grassl, P. , Davies, T. Lattice modelling of corrosion induced cracking and bond in reinforced concrete. Cement and Concrete Composites. Vol 33, 2011, p. 918-924.

10. Grassl, P., Fahy, C., Gallipoli, D., Wheeler, S.J. On a 2D hydro-mechanical lattice approach for modelling hydraulic fracture. Mechanics and Physics of Solids, Volume 75, 2015.

11. Nguyen, T.D, Pham, D.T, Vu, M.N. Thermo-mechanically-induced thermal conductivity change and its effect on the behaviour of concrete. Construction and Building Materials 198, 98-10. 2019.

12. Pham, D.T, Dung, N.T, Vu, M.N, Avirut Chinkulkijniwat. Mesoscale approach to numerical modelling of thermo-mechanical behaviour of concrete at high temperature. European Journal of Environmental and Civil Engineering, 2019 .

13. Pham, D.T., Vu, M.N., Trieu, H.T, Bui, T.S, Nguyen-Thoi, T. A thermo-mechanical meso-scale lattice model to describe the transient thermal strain and to predict the attenuation of thermo-mechanical properties at elevated temperature up to $800{ }^{\circ} \mathrm{C}$ of concrete. Fire Safety Journal 114 (2020), 103011

14. Picandet, V. Influence d'un endommagement mécanique sur la perméabilité et sur la diffusivité hydrique des bétons. Université de Nantes. Thèse de doctorat. 2001.

15. Saito, $\mathrm{M}$ and Ishimori, $\mathrm{H}$. Chloride permeability of concrete under static and repeated compressive loadings. Cem Concr Res. Vol. 25, pp. 803-808, 1995. 
16. Samaha, H. R. and Hover, K. C. Influence of microcracking on the mass transport properties of concrete," ACI Mater J, vol. 89, 1992, p. 416-424.

17. Teggur, A.D., Bonnet, S., Khelidj, A., Baroghel, B.V. Effect of uniaxial compressive loading on gas permeability and chloride diffusion coefficient of concrete and their relationship. Cement and Concrete research, , 2013, p131-139.

18. Tran, T.T., Ba, H.X, Thai, K.C, Vu, L.Q. Effect of Pre-compressive Stress on Chloride Permeability of Concrete for predicting the lifetime of concrete structure. Journal of Transport and Communtication Science, volume 57, 2017.

19. Nguyen, T.T, Tran T.T. Influence of compressive stress on the water permeabiity and chloride diffusivity of concrete. Processding of deformative solid mechanic XII, 8/2015.

20. Nguyen, X.T, Thai, K.C, Tran T.T. Effect of Pre-compressive Stress on Chloride Permeability of Concrete Used Anti-permeable Admixture. Journal of transport and communication, volume 1+2/2017.

21. Tuutti. K. Corrosion of steel in concrete. Swedish Cement and Concrete Research Institute, Ed., Stockholm. 1982.

22. Yang, C.C., Wang L.C "The diffusion characteristic of concrete with mineral admixtures between salt ponding test and accelerated chloride migration test" Materials Chemistry and Physics, V. 85, Issues 2-3, pp. 266-272 (2004)

23. Yang, T, Guan, B, Liu, G, Jia, Y. Modeling of Chloride Ion Diffusion in Concrete under Fatigue Loading. KSCE Journal of Civil Engineering volume 23, pages 287-294. 2019.

24. Voronoi, G. Nouvelles applications des paramètres continus à la théorie des formes quadratiques, Deuxième mémoire, Recherches sur les parallélloèdres primitifs, J. Für Reine Angew. 134, 1908, p.198-287.

25. Vu, M.N. Modélisation des écoulements dans des milieux poreux fracturés par la méthode des équations intégrales singulières. PhD Thesis. Ecole des Ponts ParisTech. 2012.

26. Vu, M.N, Pouya, A, Seyedi, D.M. Effective permeability of three-dimensional porous media containing anisotropic distributions of oriented elliptical disc-shaped fractures with uniform aperture. Advances in Water Resources ; 118, 2018, p.1-11.

27. Vu, M.N, Nguyen, S.T., Vu, M.H. Modeling of fluid flow through fractured porous media by a single boundary integral equation. Engineering Analysis with Boundary Elements; 59, 2015, 166-171.

28. Wang, J., Basheer, P.A.M, Nanukuttan, S.V, Long, A.E, Bai, Y. Influence of service loading and the resulting micro-cracks on chloride resistance of concrete. Construction and Building Materials. Vol 108, 1, 2016, p. 56-66.

Eksperymentalne i mezoskopowe badanie numeryczne sieci krystalicznej wzrostu współczynnika dyfuzyjności chlorków podczas jednoosiowego modelu obciążnia

W artykule przedstawiono wyniki doświadczalne i symulacyjne zmiany współczynnika dyfuzji chlorków betonu C40 (f'c $=40 \mathrm{MPa})$ podczas obciążenia osiowego. Do pomiaru dyfuzyjności chlorków próbki betonu podczas obciążenia osiowego wykorzystano metodę badania wskazań elektrycznych. Zaproponowano mezoskopowy model sieci krystalicznej w celu opisania zmiany współczynnika dyfuzji chlorków w funkcji zmiennej uszkodzenia. W takim modelu domena materiału jest dyskretyzowana losowo przy użyciu teselacji Voronoia dla elementu transportowego i triangulacji Delaunaya dla elementu mechanicznego. W mezoskali beton składa się $z$ trzech faz: kruszywa, zaczynu cementowego i ITZ, w których zakłada się, że kruszywo jest elastyczne, natomiast osnowa cementowa i ITZ sa reprezentowane przez model uszkodzenia ze zmiękczeniem. Wyniki eksperymentalne i numeryczne pokazuja, że w pierwszym etapie, bez pęknięcia $((\sigma<40 \% \sigma m a x)$, współczynnik dyfuzji chlorków pozostaje prawie stały, natomiast w fazie inicjacji i propagacji pęknięcia ( $\sigma=60-80 \%$ omax) współczynnik dyfuzji chlorków znacznie wzrasta. Zaproponowano również empiryczny model mocy opisujący wzrost wspótczynnika dyfuzji chlorków w funkcji poziomu naprężenia i zmiennej uszkodzenia.

Słowa kluczowe: model kratowy, trwałość betonu w regionach nadmorskich, dyfuzja chlorków 